\title{
Is HPV Virus Associated with Human Breast Cancer? Time to Re-examine the Postulate. Egyptian Study
}

\author{
Nadia Mohamed EISheshtawy ${ }^{1 *}$, Marwa Mosaad Shakweer ${ }^{2}$ and Yasser Mohamed EL-Ghamrini ${ }^{3}$ \\ ${ }^{1}$ Dept. of Microbiology and Immunology Faculty of Medicine Ain Shams University, Cairo, Egypt \\ ${ }^{2}$ Dept. of Pathology, Faculty of Medicine Ain Shams University, Cairo, Egypt \\ ${ }^{3}$ Dept. of Surgery (Breast Unit) Faculty of Medicine Ain Shams University, Cairo, Egypt
}

\begin{abstract}
Background: There is increasing evidence that high-risk human papilloma virus (HPV) is involved in cancers in addition to cervical cancer. Infectious agents are thought to be responsible for approximately $16 \%$ of cancers worldwide, however there are mixed reports in the literature regarding the prevalence and potential pathogenicity of viruses in breast cancer.

Methods: We screened 30 fresh frozen breast cancer tissue specimens collected immediately postoperative from patients in Ain-Shams University Hospital for the presence of human papilloma virus (HPV) DNA by PCR and Koilocytic changes in the breast cancer tissue.

Results: Overall prevalence of HPV in malignant breast tissue was 16.7\% In addition, we found that the oncogenic characteristics of HPV associated breast cancer are very similar to HPV-associated cervical cancer. Specifically, that putative koilocytes are present in some HPV associated breast cancers.

Conclusion: The above observations indicate a likely causal role for high-risk HPV in human breast cancer and offer the possible role of HPV in breast cancer prognosis.
\end{abstract}

Keywords: Breast Cancer; Human Papillomavirus; Koilocytes; PCR

\section{Introduction}

Breast cancer is the most common cancer affecting women worldwide. 1.7 million new cases were reported in 2012, representing about $12 \%$ of all new cancer cases and about $25 \%$ of all cancers in women. Although incidence trends for older women have recently stabilized, younger women are experiencing a rising incidence ${ }^{[1]}$. Many attempts showed the association of viruses such as mouse mammary tumour virus (MMTV), herpes viruses, cytomegalovirus and human papilloma virus (HPV) in malignant breast tissue ${ }^{[2]}$. There are 200 different HPV serotypes; a small number of these called "high-risk" types are associated with cancers ${ }^{[3]}$. A role for HPV in other cancers is now well accepted as a causal role in head and neck cancers ${ }^{[4]}$.

Many studies showed the presence of HPV high-risk types 16, 18 and 33 in breast cancer specimens from different countries around the world: Italy, Norway, China, Japan, USA, Austria, Brazil, Australia, Taiwan, Turkey, Greece, Korea, Mexico, Hungary and Syria with prevelance rates ranging from $4 \%$ to $86 \%{ }^{[5,6,7,8]}$. In all studies, high-risk HPV was found in tumour tissue only and not in surrounding normal tissue, except one study done in Turkey, in which the virus was also detected in normal tissue ${ }^{[9]}$. The HPV oncoproteins E6 and E7 which have been found to interact and inactivate the two principal host cell tumor suppressor proteins $\mathrm{p} 53$ and $\mathrm{Rb}$ respectively are also shown to immortalize human mammary epithelial cells in-vitro ${ }^{[10]}$. Although the route of transmission for the virus has not been determined, women positive for both breast and cervical cancers were found to be infected with the same HPV type in both tumours ${ }^{[11]}$. Koilocytes are large epithelial cells with a vacuolated halo surrounding a dense nucleus. They are specific and indicative of HPV infection being caused by the action of HPV E5 and E6 oncoprotiens ${ }^{[12]}$.

\section{Materials and Methods:}

Sample Collection. All the patients participated in this study were diagnosed as breast cancer by clinical examination, sonomammography and ultrasound guided core biopsy at our breast unit- General surgery department- Ain shams university hospital. The study was conducted over a period of 4 months from January 2016 till April 2016. 30 malignant breast tissue specimens from patients with breast cancer were aseptically collected by one surgical team immediately after tumor resection. The sample was placed into a sterile tube and transported to the PCR Laboratory, snap frozen and stored at $-80^{\circ} \mathrm{C}$. The tumors were resected by modified radical mastectomy (MRM) in 18 cases and wide local excision with axillary clearance (WLE+Axcl) in 12 cases. 
Demographic features including age, family history, menstrual history, imaging studies were collected from medical records. None of the patients had history of cancer cervix. Evaluation of pathologic features of the tumor including tumor size, tumor type according to WHO classification, tumor grade, lymph node metastasis, marginal involvement, nipple and areola involvement, TNM stage and hormonal status was done.

According to immunohistochemical profile and DNA (microarrays), breast tumors were classified into four groups $[13,14]$ :

- $\quad$ Luminal A: ER+, PR+, Her2 -

- Luminal B: ER+,PR+, Her2 +

- Triple negative: ER-, PR-, Her2 -

- Her2: ER-, PR -, Her2 +

DNA Extraction: First, Fresh frozen breast tissue were lysed with buffer ATL \& proteinase K by adding 360 ul $\mathrm{ATL}+40 \mathrm{ul}$ proteinase $\mathrm{K}$ in a sterile $2 \mathrm{ml}$ tube incubate at $37{ }^{\circ} \mathrm{C}$ for extended period of time until tissue were completely lysed. Next, 400ul of buffer AL was added to the tube $\&$ incubate at $56{ }^{\circ} \mathrm{C}$ for $30 \mathrm{~min}$ until the mixture was very clear. Then, $400 \mathrm{ul}$ of ethanol was added, vortexed $\&$ whole solution was transferred in 2 steps to the Qiagen spin column and centrifuged at $8000 \mathrm{rpm}$ for $1 \mathrm{~min}$ in each step \& spin column was transferred to a new $2 \mathrm{ml}$ tube and was washed with Qiagen wash $1 \&$ wash2 using 500ul of wash solution . Last, Spin column was transfer to a new elution tube $\& 100$ ul of elution buffer was added to spin column and left to stand at room temperature for $5 \mathrm{~min}$, centrifuged at $6000 \mathrm{rpm}$ for $1 \mathrm{~min}$.

PCR analysis: We used (Qiagen, Dusseldorf, Germany) hot start ready to use master mix in a volume of $50 \mathrm{ul}$ +primers MYO9(5' -GCM CAG GGW CAT AAY AAT GG-3 ') and MY11(5' -CGT CCM ARR GGA WAC TGA TC-3'), for the first run of PCR using the following cycling parameters by holding at $95^{\circ} \mathrm{C}$ for 15 minutes followed by 40 cycles of $94{ }^{\circ} \mathrm{C}$ for $45 \mathrm{sec}, 55^{\circ} \mathrm{C}$ for $45 \mathrm{sec}, 72{ }^{\circ} \mathrm{C}$ for $1 \mathrm{~min}$ and final extension at $72{ }^{\circ} \mathrm{C}$ for $10 \mathrm{~min}$. This was followed by nested PCR using $2 \mathrm{ul}$ of the first PCR product added to $48 \mathrm{ul}$ of master mix containing primers $\mathrm{GP} 5+\left(5^{\prime}\right.$ -TTT GTT ACT GTG GTA GAT ACT AC-3') and GP6+(5' -GAA AAA TAA ACT GTA AAT CAT ATT C-3') with the following cycling parameters by holding at $95{ }^{\circ} \mathrm{C}$ for 15 min followed by 40 cycles of $94{ }^{\circ} \mathrm{C}$ for $1 \mathrm{~min}, 40^{\circ} \mathrm{C}$ for $1 \mathrm{~min}, 72^{\circ} \mathrm{C}$ for $1 \mathrm{~min}$ and final extension at $72{ }^{\circ} \mathrm{C}$ for 10 min. These primers were degenerate for HPV16 and 18. In addition, tissues were screened b-globin to confirm their suitability for this study. After PCR, detection of amplified product was done by agarose gel electrophoresis to detect amplified product at 150 base pair in positive cases.

Detection of koilocytic changes by Histopathology: The presence of koilocytosis in the fixed breast cancer series was assessed by light microscopy with koilocyte positive cervical cancer specimens used for comparison. Koilocytes were best characterized by the presence of large cells with relatively small, but irregular and hyperchromatic nuclei surrounded by clear and transparent cytoplasm, as shown in figures (1 to 5). Koilocytosis is restricted to the replicating basal cells and multinucleation is common in these cells ${ }^{[15]}$.

\section{Results}

Clinical and pathological characterization of patients who participated in the present study is described in Table 1.

Application of Multiplex PCR for detection of HPV in breast cancer tissue revealed 5 (16.7\%) out of 30 patients positive for HPV as shown in graph (1) and figure (6).

Regarding the Clinical and pathological characterization in correlation with the PCR results shown in table 2 .

There was a strong correlation with highly significant values regarding the age $(\mathrm{p}$ value $=0.000), \mathrm{T}$ staging ( $p$ value $=0.002$ ) as shown in graph (2), her 2 neu ( $p$ value $=0.000)$, Koilocytic changes ( $\mathrm{p}$ value $=0.00001)$ and the PCR results for Human Papilloma Virus as shown in graph (3). While there was significant statistical values regarding the margins ( $\mathrm{p}$ value $=0.023$ ), $\mathrm{N}$ staging ( $\mathrm{p}$ value $=0.046)$ as shown in graph $(4)$, size ( $p$ value $=0.038)$ and the PCR results for Human Papilloma Virus.

Table 1: Demographic features of patients and Clinical and pathological characterization of the tumors.

\begin{tabular}{|c|c|c|}
\hline \multirow{2}{*}{ Age } & Mean \pm SD & $53.77 \pm 11.00$ \\
\hline & Range & $38-84$ \\
\hline \multirow{2}{*}{ Marital Status } & married & $23(76.7 \%)$ \\
\hline & single & $7(23.3 \%)$ \\
\hline \multirow{2}{*}{ TLC } & Mean $\pm S D$ & $7.06 \pm 1.54$ \\
\hline & Range & $5-9.4$ \\
\hline \multirow{2}{*}{ Neutrophils } & Mean $\pm S D$ & $56.30 \pm 8.49$ \\
\hline & Range & $46-71$ \\
\hline \multirow{2}{*}{ Lymphocytes } & Mean $\pm S D$ & $33.90 \pm 7.93$ \\
\hline & Range & $18-45$ \\
\hline
\end{tabular}




\begin{tabular}{|c|c|c|}
\hline \multirow{2}{*}{ Age } & Mean $\pm S D$ & $53.77 \pm 11.00$ \\
\hline & Range & $38-84$ \\
\hline \multirow{2}{*}{ Monocytes } & Mean $\pm S D$ & $6.07 \pm 1.76$ \\
\hline & Range & 3-9 \\
\hline \multirow{2}{*}{ Eosinophils } & MeanıSD & $2.43 \pm 0.82$ \\
\hline & Range & $0-4$ \\
\hline \multirow{2}{*}{ Heamoglobin } & Mean $\pm S D$ & $12.64 \pm 1.15$ \\
\hline & Range & $11-14.4$ \\
\hline \multirow{2}{*}{ Platelets } & Mean $\pm S D$ & $334.60 \pm 55.33$ \\
\hline & Range & $248-424$ \\
\hline \multirow{4}{*}{ Ultra sound } & BIRAD III & $2(6.7 \%)$ \\
\hline & BIRAD IV & $4(13.3 \%)$ \\
\hline & BIRAD V & $20(66.7 \%)$ \\
\hline & BIRAD VI & $4(13.3 \%)$ \\
\hline \multirow{3}{*}{ Site } & bilateral & $4(13.3 \%)$ \\
\hline & left & $14(46.7 \%)$ \\
\hline & right & $12(40.0 \%)$ \\
\hline \multirow{2}{*}{ Size } & Mean士SD & $3.76 \pm 1.59$ \\
\hline & Range & $2-7$ \\
\hline \multirow{2}{*}{ Nipple/skin affection } & No & $25(83.3 \%)$ \\
\hline & Yes & $5(16.7 \%)$ \\
\hline Tumor histologic type & $\begin{array}{l}\text { IDC } \\
\text { ILC } \\
\text { DCIS }\end{array}$ & $\begin{array}{c}16(53.3 \%) \\
8(26.7 \%) \\
6(20 \%)\end{array}$ \\
\hline \multirow{4}{*}{ T stage } & T1 & $1(3.3 \%)$ \\
\hline & T2 & $22(73.3 \%)$ \\
\hline & T3 & $5(16.7 \%)$ \\
\hline & $\mathrm{T} 4$ & $2(6.7 \%)$ \\
\hline \multirow{2}{*}{ Focality } & multifocal & $10(33.3 \%)$ \\
\hline & unifocal & $20(66.7 \%)$ \\
\hline \multirow{2}{*}{ Surgery type } & MRM & $18(60 \%)$ \\
\hline & WLE+ Axcl & $12(40 \%)$ \\
\hline \multirow{2}{*}{ Grade } & II & $24(80.0 \%)$ \\
\hline & III & $6(20.0 \%)$ \\
\hline \multirow{2}{*}{ Lumina A \& Luminal B } & No & $8(26.7 \%)$ \\
\hline & Yes & $22(73.3 \%)$ \\
\hline \multirow{4}{*}{ Her2 neu } & 0 & $24(80.0 \%)$ \\
\hline & 1 & $2(6.7 \%)$ \\
\hline & 2 & $2(6.7 \%)$ \\
\hline & 3 & $2(6.7 \%)$ \\
\hline \multirow{2}{*}{ Triple negative } & No & $28(93.3 \%)$ \\
\hline & Yes & $2(6.7 \%)$ \\
\hline \multirow{4}{*}{ N stage } & NO & $12(40.0 \%)$ \\
\hline & N1 & $9(30.0 \%)$ \\
\hline & N2 & $3(10.0 \%)$ \\
\hline & N3 & $6(20.0 \%)$ \\
\hline \multirow{2}{*}{ Koilocytic changes } & Negative & $20(66.7 \%)$ \\
\hline & Positive & $10(33.3 \%)$ \\
\hline \multirow{2}{*}{ PCR } & Negative & $25(83.3 \%)$ \\
\hline & Positive & $5(16.7 \%)$ \\
\hline
\end{tabular}

IDC: Invasive duct carcinoma, ILC: Invasive lobular carcinoma, DCIS: Duct carcinoma in situ, HP: Hormone positive, MRM: Modified radical mastectomy, WLE+Axcl: Wide local excision with axillary clearance, BIRADS: Breast Imaging Reporting and Data System. 
Table 2: Clinical and pathological characterization in correlation with the PCR results

\begin{tabular}{|c|c|c|c|c|c|}
\hline & & \multirow{2}{*}{$\begin{array}{c}\text { Negative PCR } \\
n=25\end{array}$} & \multirow{2}{*}{$\begin{array}{c}\text { Positive PCR } \\
n=5\end{array}$} & \multicolumn{2}{|c|}{ Chi-square test } \\
\hline & & & & $X^{2}$ & P-value \\
\hline \multirow{2}{*}{ Age } & Mean $\pm S D$ & $50.76 \pm 6.82$ & $68.80 \pm 16.10$ & \multirow{2}{*}{-4.201} & \multirow{2}{*}{$0.000 \mathrm{HS}^{*}$} \\
\hline & Range & $38-63$ & $52-84$ & & \\
\hline \multirow{2}{*}{ Marital Status } & married & $20(80.0 \%)$ & $3(60.0 \%)$ & \multirow{2}{*}{0.932} & \multirow{2}{*}{0.334 NS } \\
\hline & single & $5(20.0 \%)$ & $2(40.0 \%)$ & & \\
\hline \multirow{2}{*}{ Neutrophils } & Mean $\pm S D$ & $57.16 \pm 8.92$ & $52.00 \pm 4.18$ & \multirow{2}{*}{1.253} & \multirow{2}{*}{$0.220 \mathrm{NS}$} \\
\hline & Range & $46-71$ & $48-58$ & & \\
\hline \multirow{2}{*}{ Lymphocytes } & Mean $\pm S D$ & $32.84 \pm 8.01$ & $39.20 \pm 5.36$ & \multirow{2}{*}{-1.688} & \multirow{2}{*}{0.103 NS } \\
\hline & Range & $18-44$ & $34-45$ & & \\
\hline \multirow{2}{*}{ Monocytes } & Mean $\pm S D$ & $6.08 \pm 1.78$ & $6.00 \pm 1.87$ & \multirow{2}{*}{0.091} & \multirow{2}{*}{0.928 NS } \\
\hline & Range & $3-9$ & $4-8$ & & \\
\hline \multirow{2}{*}{ Eosinophils } & Mean $\pm S D$ & $2.44 \pm 0.71$ & $2.40 \pm 1.34$ & \multirow{2}{*}{0.098} & \multirow{2}{*}{0.922 NS } \\
\hline & Range & $2-4$ & $0-3$ & & \\
\hline & Mean \pm SD & $12.66 \pm 1.08$ & $12.56 \pm 1.60$ & 0168 & 0 868NS \\
\hline HemoglobIn & Range & $11.2-14.4$ & $11-14.2$ & 0.168 & $0.868 \mathrm{NS}$ \\
\hline Dlatolot & Mean $\pm S D$ & $341.24 \pm 52.96$ & $301.40 \pm 60.91$ & 1501 & 114NC \\
\hline Platelet & Range & $248-424$ & $260-407$ & 1.501 & $0.144 \mathrm{NS}$ \\
\hline & bilateral & $4(16.0 \%)$ & $0(0.0 \%)$ & & \\
\hline site & left & $10(40.0 \%)$ & $4(80.0 \%)$ & 2.829 & 0.243 NS \\
\hline & right & $11(44.0 \%)$ & $1(20.0 \%)$ & & \\
\hline & Mean $\pm S D$ & $3.50 \pm 1.48$ & $5.10 \pm 1.64$ & & \\
\hline Size & Range & $2-7$ & $2.5-6.5$ & -2.183 & $0.038 \mathrm{NS}$ \\
\hline ninnlolakin & No & $22(88.0 \%)$ & $3(60.0 \%)$ & 2350 & \\
\hline nıpple/skın & Yes & $3(12.0 \%)$ & $2(40.0 \%)$ & 2.352 & $0.125 \mathrm{NS}$ \\
\hline & IDC & $12(48 \%)$ & $4(80 \%)$ & & \\
\hline Tumour type & ILC & $8(32 \%)$ & 0 & 2.4 & $0.301 \mathrm{NS}$ \\
\hline & DCIS & $5(20 \%)$ & $1(20 \%)$ & & \\
\hline & T1 & $1(4.0 \%)$ & $0(0.0 \%)$ & & \\
\hline & T2 & $21(84.0 \%)$ & $1(20.0 \%)$ & & \\
\hline I stage & T3 & $3(12.0 \%)$ & $2(40.0 \%)$ & 14.487 & $0.002 \mathrm{HS}^{\star}$ \\
\hline & $\mathrm{T} 4$ & $0(0.0 \%)$ & $2(40.0 \%)$ & & \\
\hline Encality & Multifocal & $10(40.0 \%)$ & $0(0.0 \%)$ & 3000 & O 083 NS \\
\hline rocallty & Unifocal & $15(60.0 \%)$ & $5(100.0 \%)$ & 3.000 & 0.083 NS \\
\hline Grado & II & $19(76.0 \%)$ & $5(100.0 \%)$ & 1500 & \\
\hline Grade & III & $6(24.0 \%)$ & $0(0.0 \%)$ & 1.500 & $0.221 \mathrm{NS}$ \\
\hline lumingl o lumingl & 0 & $6(24.0 \%)$ & $2(40.0 \%)$ & 0515 & 0160 NC \\
\hline Iumınal A \& lumınal B & 1 & $19(76.0 \%)$ & $3(60.0 \%)$ & 0.545 & $0.460 \mathrm{NS}$ \\
\hline & negative & $23(92.0 \%)$ & $1(20.0 \%)$ & & \\
\hline hor? & 1 & $2(8.0 \%)$ & $0(0.0 \%)$ & 23100 & ค คח० UC* \\
\hline ner2 & 2 & $0(0.0 \%)$ & $2(40.0 \%)$ & 23.100 & 0.000 HS^ \\
\hline & 3 & $0(0.0 \%)$ & $2(40.0 \%)$ & & \\
\hline & 0 & $23(92.0 \%)$ & $5(100.0 \%)$ & & O 512 NC \\
\hline Triple negative & 1 & $2(8.0 \%)$ & $0(0.0 \%)$ & 0.429 & $0.513 \mathrm{NS}$ \\
\hline & No & $12(48.0 \%)$ & $0(0.0 \%)$ & & \\
\hline$N$ ctore & $\mathrm{N} 1$ & $5(20.0 \%)$ & $4(80.0 \%)$ & مחת & $0 \Omega 10 \mathrm{c}$ \\
\hline N stage & N2 & $3(12.0 \%)$ & $0(0.0 \%)$ & 8.000 & 0.0465 \\
\hline & N3 & $5(20.0 \%)$ & $1(20.0 \%)$ & & \\
\hline Koilooutio on & Negative & $23(92 \%)$ & $0(0.0 \%)$ & & \\
\hline Kollocytıc changes & positive & $2(8 \%)$ & $5(100.0 \%)$ & 3 & $5^{x}$ \\
\hline
\end{tabular}

IDC: Invasive duct carcinoma, ILC: Invasive lobular carcinoma, DCIS: Duct carcinoma in situ, HP: Hormone positive, MRM: Modified radical mastectomy, WLE: Wide local excision, BIRADS: Breast Imaging Reporting and Data System . 




Fig. 1a, 1b and 2a, 2b: two cases of invasive duct carcinoma showing epithelial cells with koilocytic changes (arrows) in the form of clear cytoplasm and condensed nucleus (H\&E; original magnification: 1a and 2a x200, 1b and 2b x400).

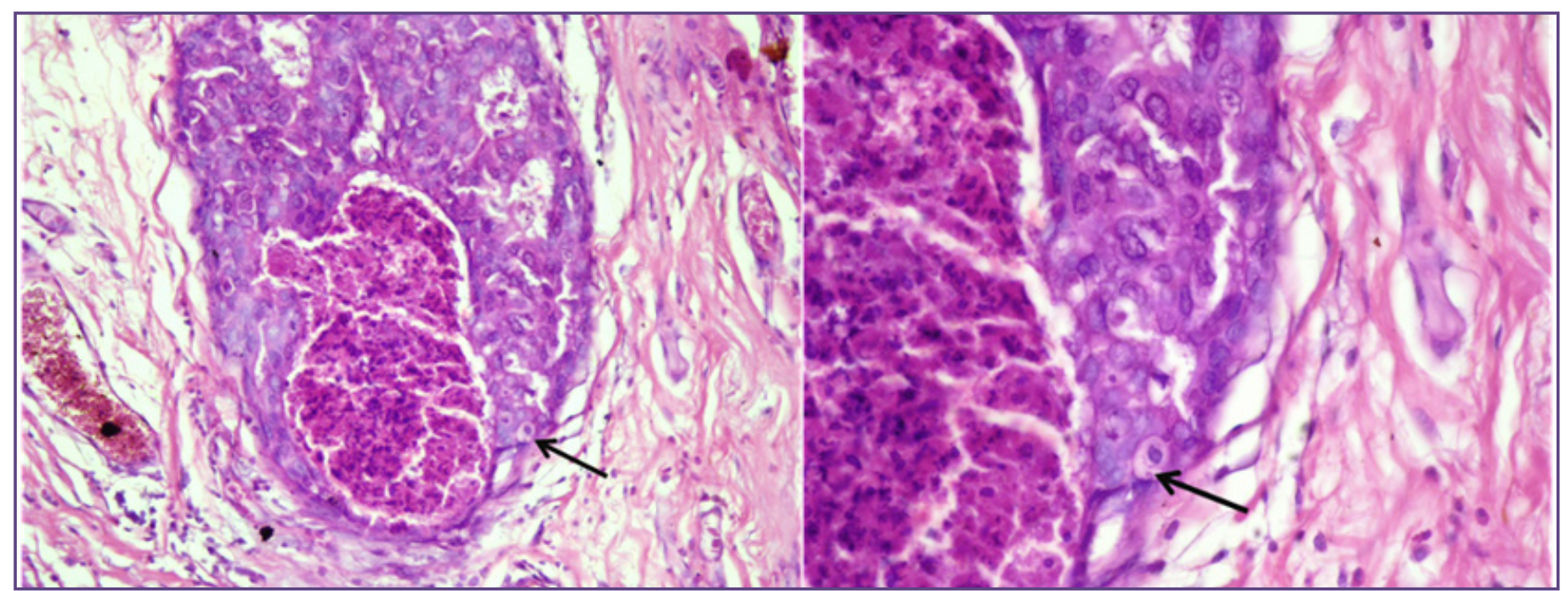

Fig. 3a, 3b: Duct carcinoma in situ; comedo type with occasional koilocytic changes (arrows) (H\&E; original magnification: $3 \mathrm{ax} 200,3 \mathrm{bx400)}$. 


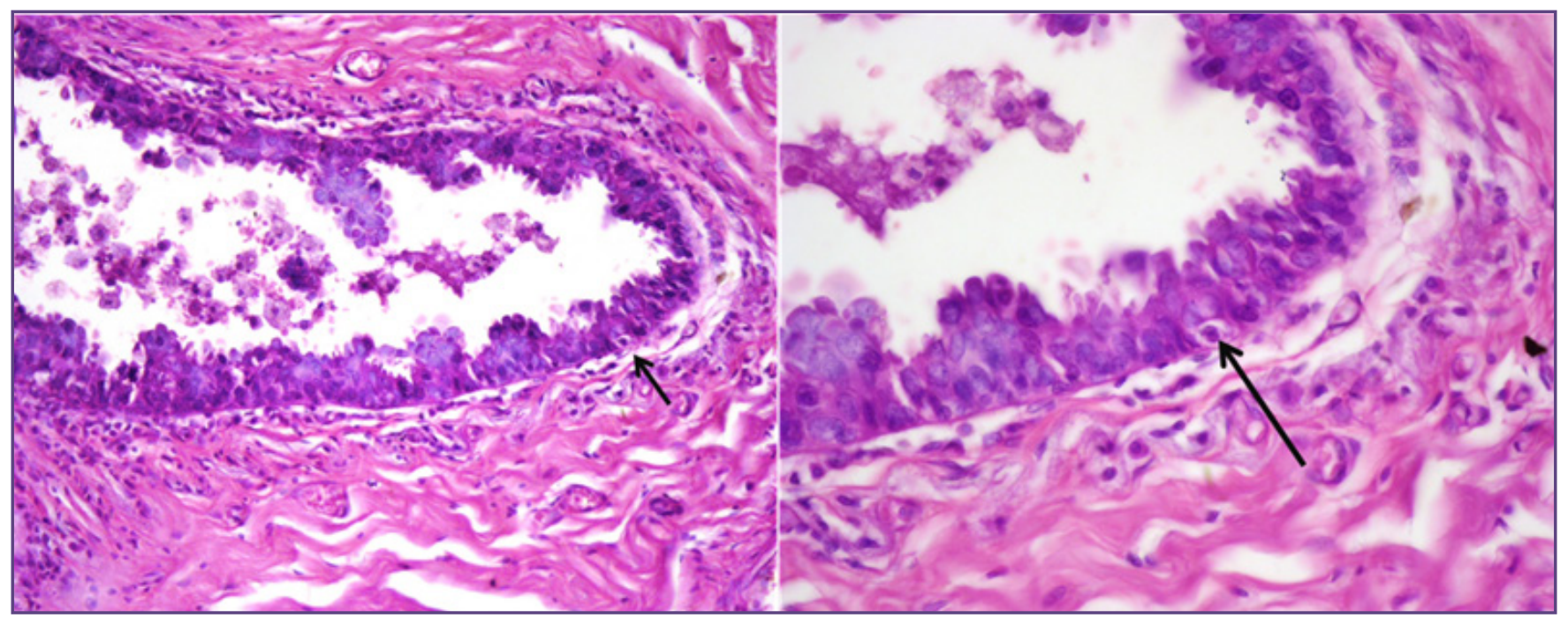

Fig. 4a, 4b: Duct carcinoma in situ; micropappillary type with occasional koilocytic changes at the basal layer (arrows) (H\&E; original magnification: 4ax200, 4bx400).

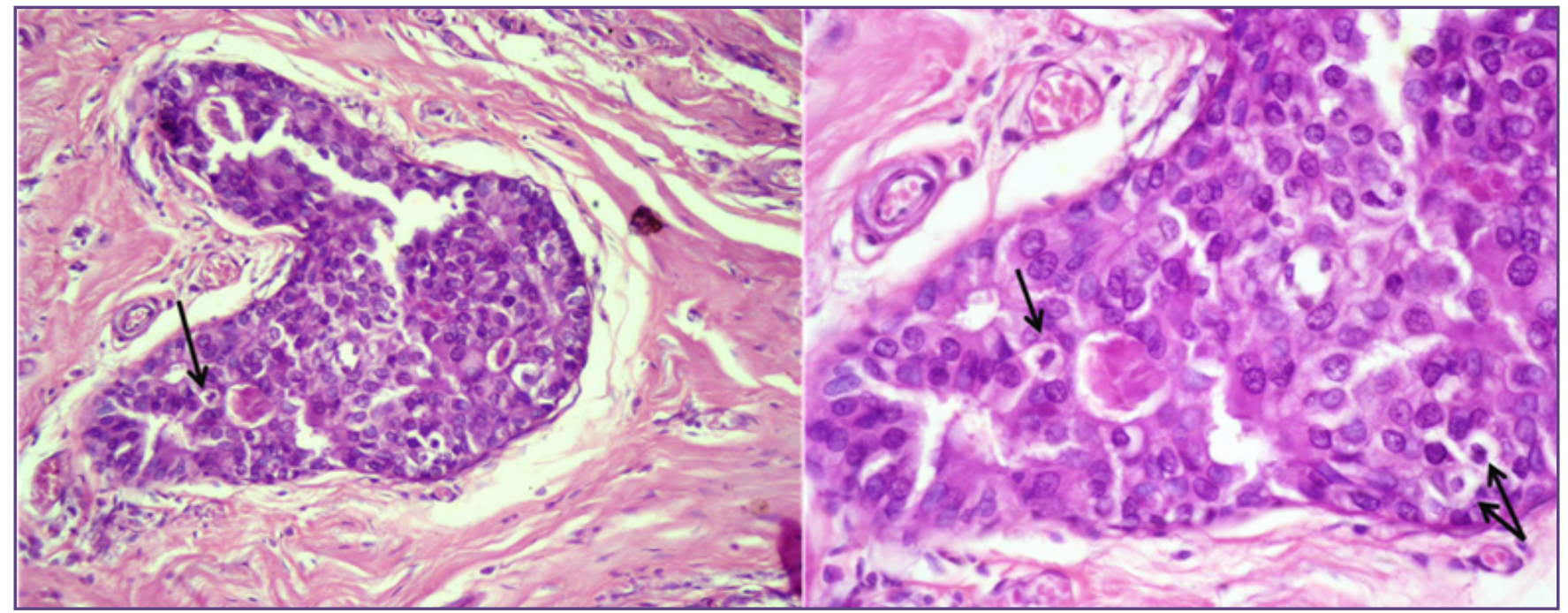

Fig. 5a, 5b: Duct carcinoma in situ; cribriform type with occasional koilocytic changes (arrows) (H\&E; original magnification: $5 \mathrm{ax} 200,5 \mathrm{bx} 400)$.



Fig. 6: Gel electrophoresis showing positive samples number $(3,6,7,10$ and 11$)$. 


\section{Discussion}

HPV infection was diagnosed in $16.7 \%$ of breast carcinoma cases, involving $33.3 \%$ of Invasive Ductal Carcinoma cases and $16.7 \%$ of Duct Carcinoma in situ cases included in this study, while all cases of Invasive lobular Carcinoma were negative for HPV infection.

We used multiplex PCR in association with routine H\&E examination for koilocytic changes to confirm the presence of HPV infection. Another Egyptian study reported HPV infection in $24.3 \%$ of invasive breast carcinoma cases, but they used immunohistochemistry in their study ${ }^{[16]}$. Many studies have reported variable prevalence of HPV infection in breast carcinoma cases. Our results were comparable to an Australian study ${ }^{[15]}$ which identified high-risk HPV DNA sequences in the nuclei of breast cancer epithelial cells in $(39 \%)$ of duct carcinoma in situ and $(23 \%)$ of invasive duct carcinoma breast cancer specimens. The noticeable lower percentage of HPV involvement in Duct Carcinoma in situ in our series may be attributed to lower number of cases and sampling techniques. On the other hand a Chinese study from Hong Kong reported negative HPV sequences in all blood and breast tissues by real time PCR performed on 102 cases of breast carcinomas ${ }^{[17]}$. Also Lindel etal. ${ }^{[18]}$ conducted a study on 81 Swiss breast cancer females who were negative for HPV DNA by PCR and stated that the role of HPV in etiology of breast carcinoma was not supported. These discrepancies in prevalence indicate that ethnic differences play a role in susceptibility to HPV infection and consequently associated breast cancer. Other factors include variability in sample size, differences in immunological and molecular methods, and inter-laboratory variability in sample collection and handling. Also false positive results may be acquired by PCR because it can't indicate which type of cells the virus has infected, as HPV was reported to be present in normal breast tissue as well or contamination while handling the sample may be a possible cause ${ }^{[18]}$. In our study we tried to minimize these errors by combining the use of $\mathrm{H} \& \mathrm{E}$ sections for detection of koilocytosis in association with PCR results to increase the accuracy of diagnosis. We didn't use immunohistochemistry for HPV because of its low sensitivity, as proved P. DeVilliers etal. ${ }^{[19]}$ who reported negative immunohistochemical expression of all high risk HPV cases that were positive for PCR, yet other studies demonstrated positive P16 in cases negative for HPV ${ }^{[20]}$.

Regarding the Clinical and pathological characterization in correlation with the PCR results in this study; there was a highly statistically significant correlation between HPV and the mean for age. The patients with proved HPV infection had a significantly older age than those without HPV infection. These results are contrary to Girianelli et al
${ }^{[21]}$ and Akarolo-Anthony et al ${ }^{[22]}$ who observed a reduction in high-risk HPV prevalence with aging.

Regarding the relationship between HPV and prognostic factors of breast cancer, we detected a statistically significant correlation between HPV positive cases and tumor size $(P=0.38)$, lymph node metastasis ( $\mathrm{N}$ stage) $(p=0.046)$ and tumor stage (T stage) $(P=0.002)$; all the cases in our study presented by T4 were positive for HPV. We assume that HPV doesn't only play a role in etiology of breast carcinoma, but is implicated also in tumor progression and spread. The link between HPV and tumor metastasis was be explained by Yasmeen et al. ${ }^{[23]}$ and Akil et al. ${ }^{[2]}$ who detected an association between high risk HPV and the upregulated expression of Id-1 transcription factor in aggressive breast cancer tissues and suggested that the virus can induce cell invasion and metastasis via Id-1. Also, Cavuslu et al. ${ }^{[25]}$ supported our hypothesis by proving that HPV was predictive of metastasis in their series of patients with cervical carcinoma. Contrary to our results, Fernandes et al. ${ }^{[26]}$ found that HPV positive cases were found mainly among groups of $\mathrm{T} 1$ and $\mathrm{T} 2$ lesions with a maximum size of $50 \mathrm{~mm}$, and suggested that HPV could have an important role in growth pattern and metastatic potential of breast carcinomas with better prognosis. On the other hand, HPV was not found to have any prognostic value in breast carcinoma as proved by Francis ${ }^{[27]}$.

In our study none of the triple negative cases were associated with HPV infection and the results were statistically not significant. However, there was a highly statistically significant positive correlation between HPV infection and Her2 neu positive cases. These results were unlike the study of done by Fernandes et al. ${ }^{[26]}$ who reported that Her 2 positive cases were negative for HPV infection, while the association between HPV infection and triple negative cases reached a statistically significant value. While Piana et al. ${ }^{[28]}$ recorded HPV positivity in $15 \%$ of cases of triple negative breast carcinoma in an Italian case control study. $W$ e recommend more investigations on the link between molecular subtypes of breast carcinoma and susceptibility to HPV infection is recommended to be investigated.

\section{Conclusion}

Findings of the current study support the previously reported association between HPV and Breast cancer. Also suggests the role of HPV in tumor progression and spread.

\section{Acknowlegment}

The authors are grateful to members of Microbiology and Immunology Department, members of Pathology Department and members of Surgery Department Faculty of Medicine, Ain Shams University, for their great support and permission to carry out this study. 


\section{Refrences}

1. Howlader N et al. SEER Cancer Statistics Review, 19752010. National Cancer Institute. Bethesda, MD 2013, http:// seer.cancer.gov/ csr/1975_2010/, based on November 2012 SEER data submission, posted to the SEER web site, April.

2. Joshi D, Buehring GC. Are viruses associated with human breast cancer? Scrutinizing the molecular evidence. Breast Cancer Res Treat 2012;135:1-15,

3. World Health Organization International Agency for Research on Cancer): Human Papilloma viruses. 1995,Vol.64.

4. Van Houten VM, Snijders PJ, Van den Brekel MW et al.: Biological evidence that human papilloma viruses are etiologically involved in a subgroup of head and neck squamous cell carcinomas .Int.J. Cancer 2001, 93,232-235.

5. Lonardo DA, Venuti A, Marcante ML: Human papillomavirus in breast cancer. Breast Cancer Res Treat 1992, 21: 95-100.

6. Liu Y, Klimberg VS, Andrews NR, Hicks CR, Peng H, Chiriva-Internati M,Henry-Tillman R, Hermonat PL: Human papillomavirus DNA is present in a subset of unselected breast cancers. J Hum Virol 2001, 4: 329-334.

7. Choi YL, Cho EY, Kim JH, Nam SJ, Oh YL, Song SY, Yang JH, Kim DS: Detection of human papillomavirus DNA by DNA chip in breast carcinomas of Korean women. Tumour Biol 2007, 28: 327-332.

8. Mendizabal-Ruiz AP, Morales JA, Ramı'rez-Jirano LJ, Padilla-Rosas M, Mora'n-Moguel MC, Montoya-Fuentes $\mathrm{H}$. Low frequency of human papillomavirus DNA in breast cancer tissue. Breast Cancer Res Treat 2009, 114: 189-194.

9. Gumus M, Yumuk PF, Salepci T, et al. HPV DNA frequency and subset analysis in human breast cancer patients' normal and tumoral tissue samples. J Exp Clin Cancer Res 2006, 25: $515-521$.

10. Wazer DE, Liu XL, Chu Q, Gao Q, Band V: Immortalization of distinct human mammary epithelial cell types by human papillomavirus 16 E6 or E7. Proc Natl Acad Sci USA1995, 92:3687-3691.

11. Widschwendter A, Brunhuber T, Wiedemair A, MuellerHolzner E, Marth C: Detection of human papillomavirus DNA in breast cancer of patients with cervical cancer history. J Clin Virol 2004, 31: 292 -297.

12. Lawson JS, Glenn WK, Heng B et al.: Koilocytes indicate a role for human papilloma virus. Br J Cancer 2009,101 (8), 1351-1356.

13. Duarte J, Bustamante $\mathrm{M}$ and Dinizza $\mathrm{R}$ et al : Immunohistochemical profile and clinical-pathological variables in breast cancer Rev Assoc Med Bras 2011, 58(2) 178-187 DOI: 10.1016/S0104-4230(12)70178-1.

14. Sandhu R, Parker J and Jones W et al : Microarray-based gene expression profiling for molecular classification of breast cancer and identification of new targets for therapy Lab Med 2010, 41(6) 364-372
15. Heng, B., Glenn, W.K., Ye, Y., Tran, B., Delprado, W., Lutze-Mann, L., Whitaker, N.J. and Lawson, J.S.: Human papilloma virus is associated with breast cancer. British journal of cancer 2009, 101(8),1345-50.

16. Ahmed RA, Yussif SM: Immunohistochemical detection of human cytomegalovirus, Epstein-Barr virus and human papillomavirus in invasive breast carcinoma in Egyptian women: A tissue microarray study. Journal of Solid Tumors 2016;6,. DOI: 10.5430/jst.v6n2p8).

17. Ava Kwong, Candy P. Leung, Vivian Y. Shin, Enders K. O. Ng: No Evidence of Human Papillomavirus in Patients with Breast Cancer in Hong Kong, Southern China," ISRN Virology 2016, vol. 2013, Article ID 546503, 4 pages, 2013. doi: $10.5402 / 2013 / 546503$.

18. Lindel, K., Forster, A., Altermatt, H.J., Greiner, R. and Gruber, G.,: Breast cancer and human papillomavirus (HPV) infection: no evidence of a viral etiology in a group of Swiss women. The breast 2007, 16;172-177.

19. DeVilliers P, Andea A, Kerr E, Novak L, Alabama U.: Pitfalls in Diagnostic Tests for High-Risk Human Papillomavirus." Oral Surgery, Oral Medicine, Oral Pathology, Oral Radiology, and Endodontology 2010;110:e18.

20. Zhang, G., Yang, B. and Abdul-Karim, F.W.: p16 immunohistochemistry is useful in confirming high-grade squamous intraepithelial lesions (HSIL) in women with negative HPV testing. International Journal of Gynecological Pathology 2015, 34:180-186.

21. Girianelli, VR., Thuler, LCS. Silva GA. Prevalence of HPV infection among women covered by the Family Health Program in the Baixada Fluminense, Rio de Janeiro, Brazil. Revista Brasileira de Ginecologia e Obstetrícia 2010, 32;39-46.

22. Akarolo-Anthony, S.N., Famooto, A.O., Dareng, E.O., Olaniyan, O.B., Offiong, R., Wheeler, C.M. and Adebamowo, C.A.: Age-specific prevalence of human papilloma virus infection among Nigerian women. BMC public health 2014, 14;1.

23. Yasmeen A, Bismar TA, Kandouz M, Foulkes WD, Desprez PY, Al Moustafa AE: E6/E7 of HPV type 16 promotes cell invasion and metastasis of human breast cancer cells. Cell cycle (Georgetown, Tex) 2007;6:2038-2042.

24. Akil N, Yasmeen A, Kassab A, Ghabreau L, Darnel AD, Al Moustafa AE: High-risk human papillomavirus infections in breast cancer in Syrian women and their association with Id-1 expression: a tissue microarray study. British journal of cancer 2008, 99:404-407.

25. Cavuslu, S., Goodlad, J., Hobbs, C., Connor, A.M., Raju, K.S., Best, J.M. and Cason, J.: Relationship between human papillomavirus infection and overexpression of $\mathrm{p} 53$ protein in cervical carcinomas and lymph node metastases. Journal of medical virology 1997, 53;111-117. 
26. Fernandes, A., Bianchi, G., Feltri, A.P., Pérez, M. and Correnti, M.: Presence of human papillomavirus in breast cancer and its association with prognostic factors. E cancer medical science 2015, 9.

27. Francis, I.M., Al-Ayadhy, B., Al-Awadhi, S., Kapila, K, AlMulla, F.: Prevalence and correlation of human papilloma virus and its types with prognostic markers in patients with invasive ductal carcinoma of the breast in Kuwait. Sultan Qaboos University medical journal 2013, 13;527.

28. Piana, A.F., Sotgiu, G., Muroni, M.R., Cossu-Rocca, P., Castiglia, P, De Miglio, M.R.: HPV infection and triplenegative breast cancers: an Italian case-control study. Virology journal 2014, 11:, p.1.

*Corresponding author:

Nadia Mohamed EISheshtawy, Ramsis street, abassia square,Faculty of Medicine, Ain Shams Univesity Cairo, Egypt.

Phone: 00201005641949

Email: nadiamohamed@med.asu.edu.eg

Date of Submission : 04.11.2016

Date of Acceptance : 05.12.2016

Financial or other Competing Interests: None.

Date of Publication : 04.02.2017 